\title{
Emerging Strategies for Healthy Urban Governance
}

\author{
Scott Burris, Trevor Hancock, Vivian Lin, and Andre Herzog
}

\begin{abstract}
Urban health promotion is not simply a matter of the right interventions, or even the necessary resources. Urban (and indeed global) health depends to an important extent on governance, the institutions and processes through which societies manage the course of events. This paper describes the concept of governance, distinguishing between reforms aimed at improving how government works and innovations that more fundamentally reinvent governance by developing new institutions and processes of local stakeholder control. The paper highlights strategies urban governors can use to maximize their influence on the national and international decisions that structure urban life. It concludes with some observations on the limitations of local governance strategies and the importance of establishing a "virtuous circuit" of governance through which urban dwellers play a greater role in the formation and implementation of policy at the national and global levels.
\end{abstract}

KEYWORDS Governance, Government, Strategies, Urban health.

\section{INTRODUCTION}

It is proving difficult to promote a high-level and fair distribution of health in the world's rapidly growing urban settings. ${ }^{1}$ Urban health promotion is not simply a matter of the right interventions, or even the necessary resources. Urban (and indeed global) health depends, to an important extent, on governance, the institutions and processes through which societies manage the course of events. There is a growing literature on governance and its impact on health..$^{2-5}$ More importantly, people throughout the world are experimenting with governance strategies to improve urban life. This paper draws on a thematic review of urban governance innovation prepared for the Knowledge Network on Urban Settings of the WHO Commission on the Social Determinants of Health $(\mathrm{CSDH}){ }^{6}$ Here we describe the concept of governance, highlight exemplary innovations and describe strategies urban governors can use to maximize their influence on the national and international decisions that structure urban life. We conclude with some observations on the limitations of local governance strategies and topics for further study.

Burris is with Temple University's James E. Beasley School of Law, and the Center for Law and the Public's Health at Georgetown and Johns Hopkins Universities, USA; Hancock is with British Columbia Ministry of Health, Canada; Lin is with the School of Public Health at La Trobe University, Australia; Herzog is with the World Bank, USA.

Correspondence: Scott Burris, Temple University Beasley School of Law, Philadelphia, Pennysylvania, USA. (E-mail: scott.burris@temple.edu) 


\section{GOVERNANCE AND THE SOCIAL DETERMINANTS OF HEALTH}

Governance is "the management of the course of events in a social system." In the urban setting, it is "the sum of the many ways individuals and institutions, public and private, plan and manage the common affairs of the city." 8 Responsible, capable and fair public institutions continue to be vital to good governance, but governance cannot be understood as the work only of government. ${ }^{9}$ Governance is polycentric, distributed among multiple organizations exercising diverse forms of power. States do not enjoy a monopoly on governance, and themselves are often governed by non-state actors. ${ }^{10,11}$ Governance thus comprises both institutions and procedures formalized in constitutions and laws, and the many institutions-corporations, NGO coalitions—and methods of power-bribery, media campaigns-that are only obscured by equating governance with government.

Students of governance increasingly emphasize complexity, both of contemporary social and economic systems and of the governance networks that have emerged to manage them. Governance is understood not as an orderly, stable political science but as an art, a dynamic process of collective social improvisation in which a plethora of actors are striving to organize matters for their own advantage. "Governance" should therefore not be mistaken for "good governance." Any given contemporary governance system may be inefficient, corrupt or unresponsive to the needs of the governed. Aside from efficiency in delivering good results, good governance is commonly defined in terms of practical virtues rooted in human rights and the principle that governors derive their authority from the people. These include participation, fairness, decency (the degree to which rules are formed and implemented without humiliating or harming particular groups of people), accountability, sustainability and transparency. ${ }^{8}$

Governance has always developed as an adaptation to social conditions. This process of adaptation has produced some marvelous and durable institutions, practices and norms, but it cannot be expected that governance solutions devised in 1648 or 1787 or even 1948 will in every case be adequate to the conditions of the present. $^{12}$ Even the best forms of governance can be worn down by the unrelenting efforts of competing factions to game or capture the system. ${ }^{7}$ Leading thinkers on governance have criticized the tendency to treat past ways of delivering good government as the only possible forms, emphasizing the need for "democratic experimentalism" and institutional innovation. ${ }^{11-13}$ Innovation is crucial because the prevailing design principles of democratic governance-like separation of powers, or even a written Constitution-“are losing their vitality."12 Real governance may so differ from the formal rules that "the formal local government decision-making process may be largely irrelevant to what actually happens." 14 For some, taking complexity seriously means embracing the polycentric character of governance and designing governance systems that emphasize social learning and coordination rather than centralized, top-down management. ${ }^{11,15}$ One of the most important consequences of recognizing governance beyond government is the possibility of applying the norms that have traditionally constrained only states to powerful private governors. In a world in which multinational corporations and wealthy foundations may wield as much power over certain decisions as governments, people are beginning to ask whether and how private governors can be required to be fair, transparent and accountable. ${ }^{16}$ 
Governance is a necessary consideration in any program to understand and influence the social determinants of health. ${ }^{2,4}$ In the CSDH's view, the level and distribution of health in a population depend on social and environmental factors operating at various levels of social organization and unfolding over time. ${ }^{17}$ Governance reflects social structure and acts as one of the social mechanisms that sort people to unequal health outcomes by upholding existing distributions of resources like power, money and knowledge. ${ }^{18}$ Those with the power to shape events in the community are able to organize matters in ways that benefit them and externalize undesirable effects on those less able to exert influence. ${ }^{19}$ Participation in governance is at once a function and a catalyst of people's empowerment, and can therefore be seen as a pathway "linking autonomy and social engagement to health." ${ }^{20}$ Although data on the link between politics, policy and health are limited, there is some evidence that countries controlled by political parties with more egalitarian ideologies tend to have more economically redistributive policies and more equitable health outcomes. ${ }^{5}$ There is also evidence suggesting that participation in governance may be healthy for individuals and communities. ${ }^{21}$

\section{THE LANDSCAPE OF GOVERNANCE INNOVATION: FROM REINVENTING GOVERNMENT TO REINVENTING GOVERNANCE}

Our paper for the CSDH examined cases of governance innovation in areas like policing, sanitation and housing. We divided what we saw into two categories, "reinventing government" and "reinventing governance." Reinventing government involves efforts to recalibrate traditional state institutions and practices to improve their capacity, often paradoxically by ceding the implementation of policy to nonstate actors through devices like governance partnerships, self-regulation, and the use of markets as regulatory tools (for example, environmental emissions trading schemes). ${ }^{22,23}$

Many reinventing government schemes have been linked to a problematic neoliberal, smaller government ideology, and experience with measures like the privatization of water and sewer systems has not been entirely happy. ${ }^{24}$ We also found many instances of government reinvention that seemed to promote good government and healthy public policies. Participatory public expenditure management (PPEM) is an excellent example. ${ }^{25}$ Over the last two decades, participatory budgeting-in which citizens take part in budget planning, overseeing public expenditures, and monitoring delivery of goods and services-has grown from a Brazilian experiment to an international model for socially accountable urban governance. ${ }^{26}$ The reform of land-tenure registration systems is another example. Uncertainty about ownership and tenure deprives poor people of the opportunity to convert property into capital for investment or home improvement, and undermines the incentive to improve housing stock and neighborhood amenities. ${ }^{27}$ Reforms in property governance have simplified title registration systems and zoning rules. ${ }^{28}$ Similar efforts have been made to eliminate bureaucratic barriers to small business entrepreneurship. ${ }^{29}$

Reinventing governance aims more broadly to mobilize governors with little or no connection to the state. ${ }^{10,12,13}$ Innovation has entailed developing new institutions and new tools of governance that can be placed at the disposal of stakeholders acting independently of or even in competition with traditional government institutions. These typically involve NGOs deploying "soft" strategies like information sharing 
and shaming (see, for example, the People's Health Movement's alternative Global Health report ${ }^{30}$ ) but also harder market strategies like voluntary product certification schemes. ${ }^{31}$ Our review found many successful examples in the urban setting.

Community organizations have performed well in developing water and sewer systems, garbage collection, and local health promotion programs. ${ }^{32-34}$ Indeed, the World Development Report in 2006 called community participation "probably the biggest influence on the success-or failure-of public sanitation facilities." 35 Unsatisfactory results from a Thai government housing improvement program in the 1990s led to the creation of an independent public agency, the Community Organizations Development Institute (CODI). CODI has a partnership structure, with a board of government and civil society representatives, but works primarily through organizations and networks in the target communities that plan and implement housing upgrades in their own neighborhoods. As of the end of 2004, upgrading programs were proceeding on this model in 175 communities involving more than 14,000 households. ${ }^{36}$

The landscape of governance is littered with governance deficits, gaps between people's stake in governance and their access to governance institutions. ${ }^{37}$ Many governance innovators have focused on developing models of governance that ensure that people have "substantial and equal opportunities to participate directly in decisions that affect them."7,14,38 What has been called "microgovernance" involves seeding communities that have been excluded from governance with small institutions around which people can mobilize their knowledge and capacity. ${ }^{3}$ In South African townships, residents provide dispute resolution and community development services that traditional state bodies were failing to deliver through a new institution called the Peace Committee. In India, health promotion for sex workers has been built around collectives like the Durbar Mahila Samanwaya Committee in Sonagachi. ${ }^{39}$ New governance practices like these not only change how specific activities are managed, but also potentially the dynamics of the larger urban governance system.

\section{INNOVATIVE STRATEGIES FOR URBAN GOVERNANCE: HEALTHY AND POWERFUL CITIES}

Urban governors do not control many of the important determinants of urban wellbeing, from the amount of the national budget available to meet urban needs to the business decisions of leaders in the global economy. Reinventing urban governance for health is in practical terms a project of the weak. In the urban setting, it turns on poorer residents gaining a greater share of control and resources. At the national and global levels, it turns on local governors' ability to influence the upstream determinants of their situation. John Braithwaite has described a set of strategies that the winners in the global game of governance have used to advantage themselves, and asked how these methods of power used by the strong might be adapted by the weak. ${ }^{37,40}$ In this section of the paper, we apply these strategies to healthy urban governance.

\section{Build and rebuild institutions of governance to increase participation and effectiveness.}

Those who have little must manage what they have well. The traditional basics of good government remain crucial: accountability, transparency and honesty. 
Defining the territorial and subject matter jurisdiction of metropolitan government structures is also fundamental, although decades of effort have not produced a generally applicable solution. ${ }^{41} \mathrm{New}$ governance strategies of privatization and selfregulation can be tools of more efficient public management. PPEM, community policing and other practices that increase the meaningful involvement of stakeholders have shown good results, but do not replace and indeed may depend on the vitality of governance institutions outside the government. Funding (and minimizing legal barriers on) NGOs, microgovernance initiatives and institutional innovations that devolve power to stakeholders can all increase urban governance capacity by mobilizing the resources and capacities of communities that currently have no real access to governance.

\section{Network governance.}

Once a wide range of governance institutions are active, building connections among them and with compatriots in other urban settings allows the weak to increase their resources for advocacy and upstream governance. Networks like the Asian Coalition for Housing Rights and Slum/Shack Dwellers International (SDI) not only take local action but also "work together to support each other-from community to community within cities, from city to city within nations, and internationally." ${ }^{, 42}(\mathrm{p} 2),{ }^{43-45}$ The Healthy Cities Movement and regional health promotion networks, through which areas in close geographic proximity pool resources and expertise, exemplify the type of cooperation necessary to global health. ${ }^{46}$

\section{Concentrate technical competence at network nodes.}

Effective networks of governance typically create nodes on the network that "concentrate resources and technologies for the purpose of achieving a common goal." ",47 Technical expertise and the capacity to rapidly gather, interpret and respond to information helps weaker actors compete successfully with stronger ones. ${ }^{37}$ The campaign of developing countries and HIV/AIDS advocates to mitigate the impact of the TRIPS agreement on access to essential medicines demonstrated the importance of organizing networks around institutions of technical competence such as Medecines sans Frontieres and the Consumer Project on Technology. ${ }^{48}$ Another example is the health promotion foundation, like VicHealth in Australia, designed as a reliably funded source of expertise and advocacy in the cause of better health governance. ${ }^{49}$

\section{Focus on forums where urban governors can be creative and assertive.}

Many powerful governing institutions and systems are not concerned about the welfare of urban settings. "If weak actors engage in governance in and through organizational nodes that others, particularly rich and powerful others, have established and work through, they will typically find themselves at a disadvantage because they will find that the agendas of others have been built into nodal processes." 37 "Forum shifting" may be defined as relocating interactions (like negotiation or regulation) from an institution of governance in which an actor encounters resistance to one where it is likely to achieve its objective. Forum shifting has been an extremely useful tool of the powerful; it can also work for weaker players 
like cities and NGOs. Local governments are forum shifting when, for example, they file law-suits against gun makers in places where provincial and national legislatures have rejected gun-control regulation. ${ }^{50}$ PPEM creates a new forum for spending decisions in which non-state actors have more authority in relation to local government officials. ${ }^{51}$ NGOs like Peace Committees and water cooperatives also represent a forum shift: unsatisfied with the services they are getting within a scheme of government provision, they create a new service-providing institution in which they have greater control over processes and outcomes.

\section{Have a responsive regulatory strategy.}

This is a generic "best practice" of power in any forum. Responsive regulation entails using the least expensive and intrusive form of action needed to secure compliance. ${ }^{52}$ Dialogue is more efficient than threats; threats are more efficient than actually imposing sanctions. But as Braithwaite points out, a responsive strategy is more than good technique: it has two even deeper virtues. First, it represents a way of understanding governance in a democracy based on "responding to peoples' problems, environments, demands." The obligation to respond to others in the society is a vital example of the relational "checks and balances" that constrain power in a polycentric governance system. Second, responsiveness embodies the capacity for learning and the openness to new information that are characteristic of effective governance institutions. ${ }^{53}$

\section{Have a big stick and threaten to use it.}

Even responsive regulators sometimes crack down hard. Urban communities are weak in relation to national governments, multinational corporations and international donors, but they are not powerless. Urban governors have a variety of sticks, from networked advocacy and shaming strategies, through regulations and taxes, to debt default. "Weak" actors have proven reasonably effective at influencing global policy not just by speaking up for the interests of poorer regions in international fora, but by taking the battle into the media and domestic politics. ${ }^{40}$

\section{CONCLUSION: CHALLENGES OF HEALTHY URBAN GOVERNANCE}

Strong local governance has its pitfalls. ${ }^{54,55}$ Those with greater resources of experience, money or skill can game the local system as they can a national government. ${ }^{56}$ The voices of the poorer, weaker, more socially marginal can be ignored. Women may be denied the chance to speak at all. Urban settings often have large populations of "illegal" internal or international migrants whose right to participate is contested. ${ }^{57}$ Urbanites do not necessarily, or even most of the time, organize themselves and vote as urban dwellers, but rather act as members of ideological or ethnic blocks organized around national political issues that may reflect and worsen divisions at the local level. ${ }^{14}$

Urban governors are part of a system that works best as it approaches the ideal of a "virtuous circuit" (see Figure 1). At any level of social organization, governing institutions require the capacity to mobilize and coordinate local resources, but from a global governance perspective, vertical coordination and participation are 
Mobilization and Coordination

\author{
Global
}

National

Local

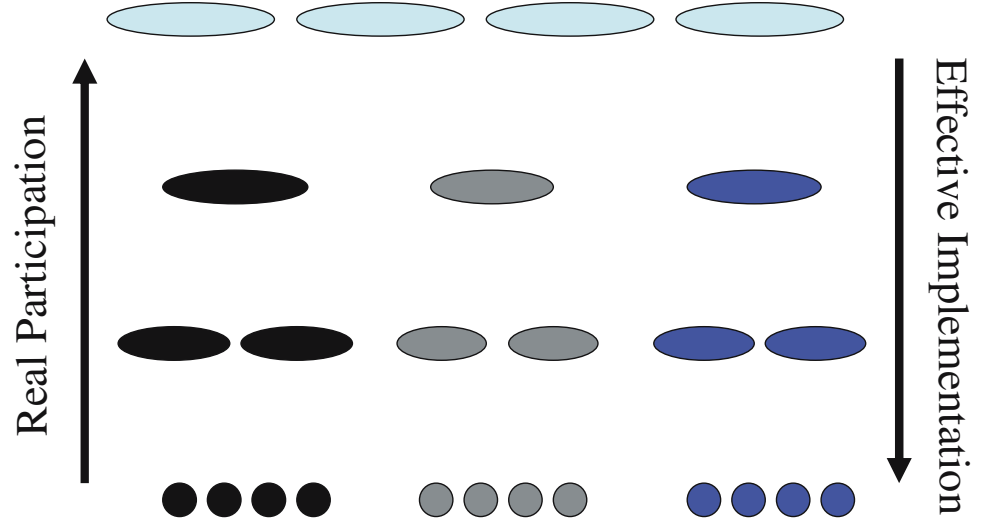

FIGURE 1. The virtuous circuit of global health governance.

essential. The best of interventions organized at the global level will suffer if the national, provincial and especially the local institutions of governance are bypassed or lack the capacity for effective implementation. Even the imposition of "good" solutions in a top-down manner, without real decision-making participation by those most affected, is paternalistic and illegitimate from a democratic perspective.

Good governance requires the interplay of power and constraint to forestall dysfunctional phenomena such as capture. Good national and international governance can be a source of norms, and a recourse for those excluded from local decision making. ${ }^{55}$ National governments provide the "policy environment" in which local government and governance can innovate, or not. ${ }^{58,59}$ It is not even clear that empowering urban areas leads to greater attention to urban inequities: "Although central governments are unlikely to be generally more 'pro-poor' than local governments, it may be easier for central governments to insist on pro-poor use of grant resources than for local governments to use their own resources in that way."14 (p 14)

Local governments typically are short not just on cash but on properly trained bureaucrats with the skills and incentives to use their power productively. The strategies we have discussed here are hardly new to local health advocates; the problem is that lack of resources can limit efficacy at every step. Improving skills in governance, widening the repertoire of strategies, will make poor urbanites more effective, but local governors also need access to the resources controlled by higher levels of governance.

The promotion of innovation in healthy urban governance will benefit from a significant investment in research and practice. On the research side, more support is required for the study of the "design principles" or grammars of successful governance, particularly outside of and in partnership with government. ${ }^{60}$ It is even more important to fund governance "entrepreneurs" reinventing governance in communities around the world, and to support ongoing community processes of governance reinvention. Investment is also necessary to sustain and build on success. Even successful models of participatory governance-and there are many-remain "feel good" stories for researchers, governments and NGOs unless they can be replicated at 
a sufficient scale to influence the condition of the mass of urbanites. ${ }^{58,61}$ International funders and governments speak about the importance of good governance and strong civil society, but investment in general governance capacity, unlinked to a particular categorical program or specific objective, is still too rare.

People can learn to better improvise, but no amount of research or technology transfer will turn governance from an art into a science. It will be difficult to prove that any particular form or process of governance causes urban health to improve, yet we have more than enough reasons to prefer good governance over the alternative. Good governance is not just valuable for the ends it promotes, but for the process of collective cultural imagination it represents. Urban settings are places where the world can be re-imagined, where efforts at reform create the context for new ideas and further action, and where new norms are formed. ${ }^{62,63}$ The world's urban settings present an enormous opportunity to define and implement healthy public policy through governance innovation.

\section{REFERENCES}

1. Galea S, Vlahov D. Urban health: evidence, challenges, and directions. Annu Rev Public Health. 2005;26:341-365.

2. Dodgson R, Lee K, Drager N. Global Health Governance: a Conceptual Review. London: London School of Hygiene and Tropical Medicine; 2002.

3. Burris S. Governance, microgovernance and health. Temple Law Rev. 2004;77:334-362.

4. Hein W. Global health governance and national health policies in developing countries: conflicts and cooperation at the interfaces. In: Hein W, Kohlmorgan L, eds. Globalization, Global Health Governance and National Health Policies in Developing Countries: an Exploration Into the Dynamics of Interfaces. Hamburg: Deutschen Uebersee-Instituts; 2003:33-71.

5. Navarro V, Muntaner C, Borrell C, et al. Politics and health outcomes. Lancet. 2006.

6. Burris S, Hancock T, Lin V, Herzog A. Emerging Principles of Healthy Urban Governance: a Background Paper for the Knowledge Network on Urban Settings. Kobe: WHO Kobe Center; 2006.

7. Burris S, Drahos P, Shearing C. Nodal governance. Aust Journal Leg Philos. 2005;30: $30-58$.

8. UN Habitat. The Global Campaign on Urban Governance: Concept Paper: UN Habitat; 2nd ed. 2002.

9. Commission on Global Governance. Our Global Neighbourhood: the Report of the Commission on Global Governance and Democratic Accountability. Oxford: Oxford University Press; 1995.

10. Kempa M, Shearing C, Burris S. Changes in governance: a background review. Accessed July 30, 2006 and Available at: http://www.healthgov.net.

11. Teubner G. Societal Constitutionalism: Alternatives to State-Centred Constitutional Theory? In: Joerges C, Sand I-J, Teubner G, eds. Transnational Governance and Constitutionalism: International Studies in the Theory of Private Law. Oxford and Portland, Oregon: Hart Publishing; 2004:3-28.

12. Dorf MC, Sabel CF. A constitution of democratic experimentalism. Columbia Law Rev. 1998;98:267-473.

13. Unger RM. What Should Legal Analysis Become. London and New York: Verso; 1996.

14. Devas N. Who Runs Cities? The Relationship between Urban Governance, Service Delivery and Poverty. Birmingham: University of Birmingham School of Public Policy; 1999. 
15. Sabel C. Beyond Principal-Agent Governance: Experimentalist Organizations, Learning and Accountability. In: Engelen E, Ho MSD, eds. De Staat van de Democratie. Democratie voorbij de Staat. Amsterdam: Amsterdam University Press; 2004:173-195.

16. Sinden A. The Power of Rights: Imposing Human Rights Duties on Transnational Corporations for Environmental Harms. In: McBarnet D, Voiculescu A, Campbell T, eds. The New Corporate Accountability: Corporate Social Responsibility and the Law. Cambridge: Cambridge University Press; 2007.

17. Solar O, Irwin A. Towards a Conceptual Framework for Analysis and Action on the Social Determinants of Health. Geneva: Commission on Social Determinants of Health; 2005.

18. Burris S, Kawachi I, Sarat A. Integrating law and social epidemiology. J Law, Med Ethics. 2002;30:510-521.

19. Maantay J. Zoning, equity, and public health. Am J Public Health. 2001;91(7):1033-1041.

20. Marmot M. Health in an unequal world. Lancet. 2006;368:2081-2094.

21. Kawachi I, Berkman L. Social Cohesion, Social Capital and Health. In: Berkman L, Kawachi I, eds. Social Epidemiology. New York: Oxford University Press; 2000:174-190.

22. Osborne D, Gaebler T. Reinventing Government. New York: Plume; 1993.

23. Rhodes RAW. Understanding Governance: policy Networks, Governance, Reflexivity and Accountability. Buckingham and Philaldephia: Open University Press; 1997.

24. Estache A, Gomez-Lobo A, Leipziger D. Utilities privatization and the poor: lessons and evidence from Latin America. World Dev. 2001;29(7):1179-1198.

25. The World Bank. The Social Accountability Sourcebook. The World Bank. Accessed December 5, 2006 and available at: http://www-esd.worldbank.org/sac/essd9.swf.

26. The World Bank. Social Accountability: an Introduction to the Concept and Emerging Practice. Washington, D.C.: The World Bank; 2004. Social Development Paper No. 76.

27. de Soto H. The Mystery of Capital: Why Capitalism Triumphs in the West and Fails Everywhere Else. New York: Basic Books; 2000.

28. Kagawa A, Turkstra A. The Process of Urban Land Tenure Formalization in Peru. In: Payne G, ed. Land, Rights and Innovation. London: ITDG Publishing; 2002:57-75.

29. Jansson T, Chalmers G. The Case for Business Registration Reform. Washington, D.C.: Inter-American Development Bank; 2001.

30. Global Health Watch. Global Health Watch 2005-06: an Alternative World Health Report. London and New York: Zed Books; 2005.

31. Spiro PJ. NGOs in International Environmental Lawmaking: Theoretical Models. Oxford Handbook of International Law. Oxford: Oxford University Press; 2007.

32. Zarsky L. From Bystanders to Collaborators: New Roles for Civil Society in Urban Industrial Environmental Governance in Asia: Nautilus Institute for Security and Sustainable Development; June 2001.

33. Memon MA. Public Participation for Urban Environmental Management: Overview and Analysis. Institute for Global Environmental Strategies.

34. Yahya SS. Community Land Trusts and Other Tenure Innovations in Kenya. Land Rights and Innovation. London: ITDG Publishing; 2002.

35. United Nations Development Programme. Human Development Report 2006: beyond scarcity: Power, Poverty and the Global Water Crisis. New York: United Nations Development Programme; 2006.

36. Boonyabancha S. Baan mankong: going to scale with "slum" and squatter upgrading in Thailand. Environ Urban. 2005;17(1):21-46.

37. Wood J, Shearing C. Imagining Security. Portland, Oregon: Willan; 2007.

38. Fung A. Empowered Participation: Reinventing Urban Democracy. Princeton: Princeton University Press; 2004.

39. Burris S. From Security to Health. In: Woods J, Dupont B, eds. Democracy and the Governance of Security. Cambridge: Cambridge University Press; 2006:196-216.

40. Braithwaite J. Methods of power for development: weapons of the weak, weapons of the strong. Mich J Int Law. 2004;26:297-330(Fall). 
41. Lefèvre C. Metropolitan government and governance in western countries: a critical review. Int J Urban Reg Res. 1998;22(1):9-25.

42. D'Cruz C, Satterthwaite D. The role of urban grassroots organizations and their national federations in reducing poverty and achieving the millennium development goals. Global Urban Development. 2006;2(1):1-17.

43. Patel S, Burra S, D'Cruz C. Slum/shack dwellers international (SDI)—foundations to treetops. Environ Urban. 2001;13(2):45-60.

44. Weru J. Community federations and city upgrading: the work of Pamoja Trust and Muungano in Kenya. Environ Urban. 2004;16(1):47-62.

45. Asian Coalition for Housing Rights. Urban Poor Asia. Asian Coalition for Housing Rights. Accessed September 23, 2006 and Available at: http://www.achr.net.

46. de Leeuw E. Global and local (glocal) health: the WHO healthy cities program. Global Change and Human Health. 2001;2(1):34-45.

47. Drahos P. Intellectual property and pharmaceutical markets: a nodal governance approach. Temple Law Rev. 2004;77:401-424.

48. Kohlmorgan L. The Role of Southern Actors in Global Governance: Access to Medicines and the Fight Against HIV/AIDS. European Consortium for Political Research Session of Workshops. Nicosia; 2006.

49. WHO Regional Office for the Western Pacific Region. Health Promotion Financing Opportunities in the Western Pacific Region. Manilla: WHO Regional Office for the Western Pacific Region; 2003.

50. Kairys D. The Cities Take the Initiative: Public Nuisance Lawsuits Against Handgun Manufacturers. In: Harcourt B, ed. Guns, Crime and Punishment in America. New York: New York University Press; 2003:363-383.

51. Souza C. Participatory budgeting in Brazilian cities: limits and possibilities in building democratic institutions. Environ Urban. 2001;13(1):159-184.

52. Ayres I, Braithwaite J. Responsive Regulation: Transcending the Deregulation Debate. New York and Oxford: Oxford University Press; 1992.

53. Braithwaite J. Responsive regulation and developing economies. World Dev. 2005;34(5):868-932.

54. Fung A. Accountable autonomy: toward empowered deliberation in Chicago schools and policing. Polit Soc. March 2001;29(1):73-103.

55. Johnson C, Deshingkar P, Start D. Grounding the state: devolution and development in India's panchayats. J Dev Stud. 2005;41(6):937-990.

56. Dahl R. Who Governs? Democracy and Power in an American City. New Haven: Yale University Press; 1961.

57. Shearing C, Wood J. Nodal governance, democracy, and the new "Denizens". J Law Soc. 2003;30(3):400-419.

58. Barten F, Montiel RP, Espinoza E, Morales C. Democratic governance-fairytale or real perspective? Lessons from Central America. Environ Urban. 2002;14(1):129-144.

59. de Vries J, Schuster M, Procee P, Mengers H. Environmental Management of Small and Medium Sized Cities in Latin America and the Caribbean. Washington: Institute for Housing and Urban Development Studies; 2001.

60. Ostrom E. Understanding Institutional Diversity. Princeton: Princeton University Press; 2005.

61. Milbert I. Slums, Slum dwellers and multilevel governance. Eur J Dev Res. 2006;18(2):299-318.

62. Castells M. The City and the Grassroots: A Cross-cultural Theory of Urban Social Movements. Berkeley: University of California Press; 1983.

63. Lake RW. Recentering the city. Int J Urban Reg Res. 2006;30(1):194-197. 